\title{
On the Modern Value of Art in the Viewpoint of Communication Studies
}

\author{
Yuming Sun \\ School of Arts \\ Northeast Dianli University \\ Jilin Province, Jilin City, China \\ e-mail: seusym@126.com
}

\begin{abstract}
As an important part of the cultural systems of human mind, art develops the original spiritual values in the social evolution by variety forms. In the field of communication, the realization process of artistic value is shown as art creation, art reception as well as self-regulation basic on communication effects. In these three sessions, art shows the diversity modern values for people, society and itself.
\end{abstract}

\section{Keywords-Communication Studies; Arts; Modern Value}

\section{INTRODUCTION}

Any things all have their value. Arts is a kind of mental activity with material, and a kind of spiritual activity with sensual. So the value of arts mainly exists in the people's spiritual level, shown as the construction and shaping of the human soul. Art is always in a process of constant development, the value of art is endowed with different meanings in different eras. The modern value of art is the inheritance of tradition and comprehensive of new era.

\section{ARTIST: THE CREATOR OF ARTISTIC VAlUE}

Only the people can create art, and understand the value of art. Regardless of how the artistic expression form and content, the creation and communication process of art is inseparable from people. The value of art is absolutely connected to the existence of people. Art is the conclusive evidence of human continuously extends the materiality as spiritual life ontology. People directly see the mental training with survival and changes of themselves, enhance their life force in the material objects.[1] It is the strong corroboration about people who are worth living. It is just so much for the highest artistic value, there can be no higher than this value, whether science or ethics have not and will not achieve the value about the meaning of life. This is the most fundamental value of art, and cannot be replaced by other forms.

The nature of art is aesthetic. So art has the aesthetic value. Embodiment of aesthetic value is the educational function of art in real life. Art incarnates rationality by the forms of sensibility, and the most important of rationality is included awareness and enlightenment on people. This traditional idea of artistic value has been discussed in ancient Greece. Aristotle said that poetry has a purifying effect on mood, beneficial to the audience's ment $a$ l health, also beneficial to the community, the pleasure from purify is harmless. The essence of purify is that making some kind of overly strong emotional catharsis and achieve peace by music or other arts, restore and maintain mental health.

In different eras, art regulates moral behavior and enriches spiritual world of people. In ancient Greece Rome arts showed pursuit of the beauty of human body and humanized of myth. In the middle ages, arts showed the worship of religion. [2] In modern times arts has more philosophical nature. In modern society, the aesthetic educational value of art does not diminish or disappear, but has been strengthened due to the attention of people "Fig. 1".

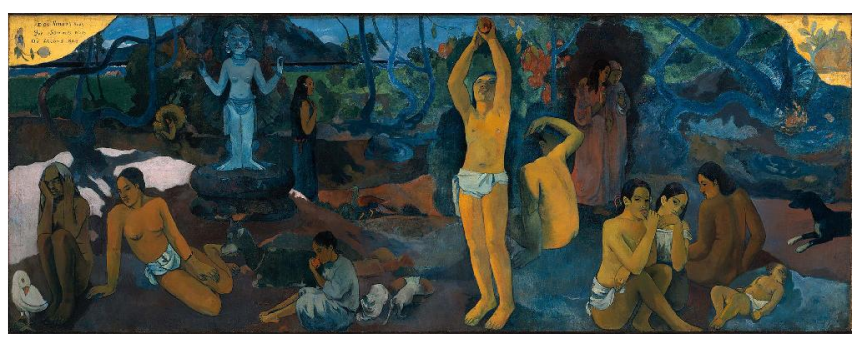

Fig. 1. Where Do We Come From? What Are We? Where Are We Going? Paul Gauguin 1897-1898

Today more and more forms of art museums, art exhibitions and art shows, make arts closer to people than any other era. Not only that, life becomes aesthetic and aesthetic turn to life with the development of modern media such as Internet communication. For example, we can appreciate music and drama at anytime or anywhere by taking advantage of modern communications equipment and networks, getting aesthetic pleasure, purifying our hearts. Art is the hometown of the human soul. There, people are free to grow, swim, trembling, orgy, pure. Art will also be the end of mankind. Only in art, human can be free and liberated. In the modern high-pressure and fast-paced life, aesthetic and educational value of art is particularly important. People need to overcome impetuous atmosphere in modern society through art, and strive for quiet mental territory for themselves. 


\section{AUDIENCE: BENEFICIARIES OF ARTISTIC VALUES}

In the art appreciation activities, Audiences are not passive, but often has the initiative of exploration and discovery. In both these fields, the special and formed composition of art on the one hand comes up, attracting people to appreciate it, on the other hand was found and perceived. In the communication of art, the audience is also a dynamic agency as the recipient of art. The appreciators actively obtain the art information for meeting their consumption needs of arts, while recreating art works with their own feelings and imagine realizing the communication with artists. Germany aesthetician Jesus says: among the triangle of author, work and mass, the mass is not the passive part. It is not a simply reaction, on the contrary, it is a dynamic form of history. It is incredible that life-history of a literary work without the active participation of recipients. It is because only through transfer process of reader that works can turn into a continuous change of experience vision.

When the artist completed work, the value of art is not really achieved, the intrinsic value and function of the work is just a kind of potential energy. Only through appreciation activity, this possibility will be translated into reality. If the artists put their works on the shelves, then no matter how rich contents and how high artistic value, they would be just a bunch of physical objects with art symbols.

In the aesthetics reception theory, these will be called "TEXT" which ware not entrance the appreciation actives. This "TEXT" is not satisfactory, just a sense of space and uncertainty before the appreciator touch the art works. When the "TEXT" Denys the habitual perspective, will cause blank in the mentality of appreciator. [3] All these gaps, vacancies, the negative factors compose the negative structure of art works, which become the basic drives, inspired and induces appreciation for creative fill and imaginative connection. Their uncertainty components enabled the exchange between text and reader. In this sense, they lure readers to participate the formulation and understanding of art intention.

The receive activity of art appreciator is not only the supplement and perfect to art work, but also the creative process. United States philosopher John Dewey said: "in order to be perceived, the Viewer had to create his own experience. And his creation must be included with the similar experiences that original creators endured. They are not the same in the literal sense. However, the perceiver must have an integral component of adjustment, just as artists, it is same with organization process that creator experience in consciousness not in detail, but in the form.

If there is not a re-creation of the action, the object could not be perceived as art works. In the reception of art, although the recreation activities of appreciators have a certain degree of subjectivity and freedom, they can not completely separate from art works to create randomly. The artistic creations is dynamic processes include observation, perception, condensation and creation. As well in the receive acceptation, appreciators need carry out a reveres engineer and combined with artistic background information to complete the re-creation of original art works.
If we analyze the realize process of artistic creation and art works from the perspective of the aesthetics reception theory, it is the appreciator-centered. It appears that we can think: Artist as a creative subject should be carried out creation for the appreciator. It just as dufuhaina said: one never exhibited painting, a copy of unpublished manuscript, one without performance play script, is not the objects eligible among the cultural world. Because they are not yet fully exist. [4] Artists might say that these are his works, and they exist because they have been created. But he hopes that these works also exist for others, and accepted by public assessment. Art works get their plenty of reality through the appreciator. Although the value of any art work is objective existence, it needs the reader to discover. In other words, the art works artists created must through out the aesthetic and creative activity, and then it can really fulfill its social and aesthetic values. It is that both alive and continuity change of art works are dependent on the appreciation of audience. Moreover, the subject of appreciation activity is not passively, but actively carrying on aesthetic recreation.

\section{COMMUNICATION EFFECTS: THE UltimATE REALIZATION OF ARTISTIC VALUES}

The implementation of artistic values is its function, which is the reflection in the real world. This function is defined from a macroscopic perspective of the social and artistic. The value of art constantly expanded and enriched along with social development. Modern value of art is more shown as introspection of social reality and fullest of the art concept. The development of arts has always been closely associated with the real-life together. [5] Art is a unique picture of recorded human history. Arts has come throng the primitive worship of nature, the myths of ancient Greece and Roman, religious prisoner in the middle ages and the modern wild, the primary modern value of art is introspection of social reality. Arts make modern people to think themselves and explore the society in which we live by stark expressive and sensuous forms "Fig. 2".

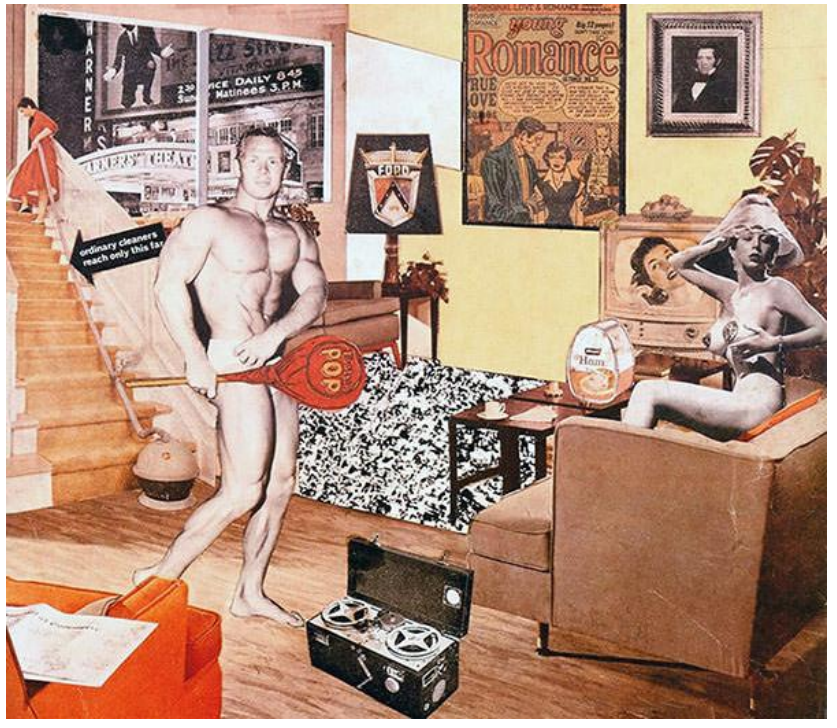

Fig. 2.Just what is it that makes today's homes so different, so appealing? Richard Hamilton 1956 
When Marx evaluated the works of United Kingdom writers such as Dickens, Thackeray in the 19th century, he said: the political and social truths revealed in their brilliant and vivid books are more than any professional politicians, publicists and moralists did. So that people can break through the limitations of time and space, and have more comprehensive understanding of the social life about ancient and modern. Mr. Lu Xun reflected the reality of Chinese society around the Revolution of 1911 by creating a series of stereotypes, this also shown his spirit of uncompromising anti-imperialism and anti-feudalism and his deepen thought about Chinese society.

Art work restores the richness of life. What people get from here, is not the deflated figures, nor narrative without feeling like a chronicle, not a lecture, but the world full of living, breathing, with desire, passion, joy, sadness, love, and death and suffering. The painting named the gleaners created by France realist painter Miller which is seemed as the indictment of the poverty of the people "Fig. 3". There are the ricks, carriages, busy farm laborers and riding overseer in far distance. In the foreground of the painting, there are three poor women bending over to pick up residuary wheat in the field, one of them is working without said anything, and the other woman is so tired that having a little rest. Picture was unified in orange tones, strongly described the poverty of farmer in the harvest season.

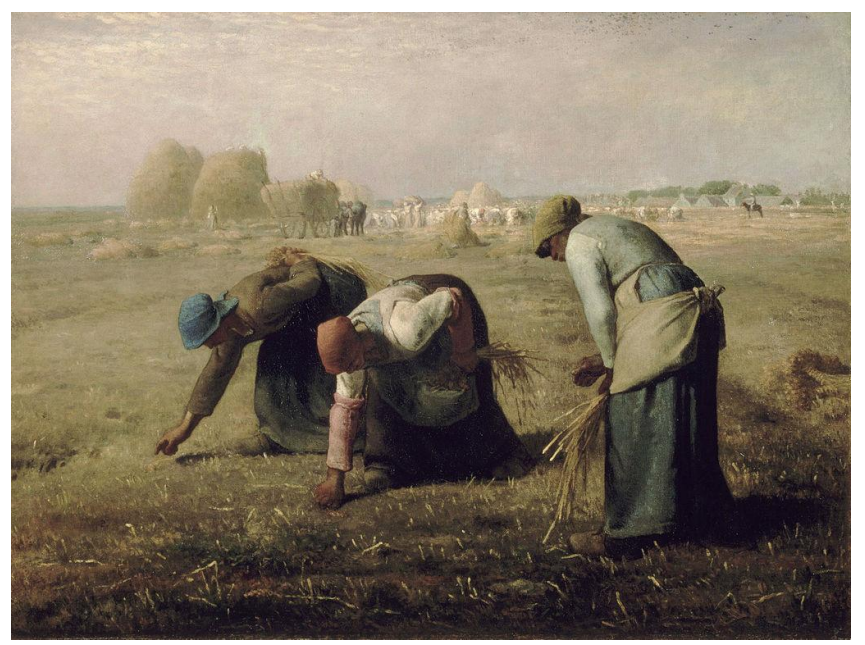

Fig. 3. The Gleaners Jean-François Millet 1857

Another example, the dinner party is the art work of famous artist Judy Chicago which mobilized more than 400 people took part in the cooperation to complete the giant installation art works from 1973 to 1979 "Fig. 4". The works records a total of 1038 names of outstanding women in history, 999 names are engraved on the center floor and the other 39 women are symbolized by 39 tables. Plates were set on each table which painted bright patterns implying female sex organs, representing the seat of great women. The embroidery and text on tablecloth records the periods and identity of the women. Judy Chicago has high hopes for this installation with a certain political objectives. She hope all of us can take this to recognize women's contributions to history, also expressed the wish that the world could be reformed.

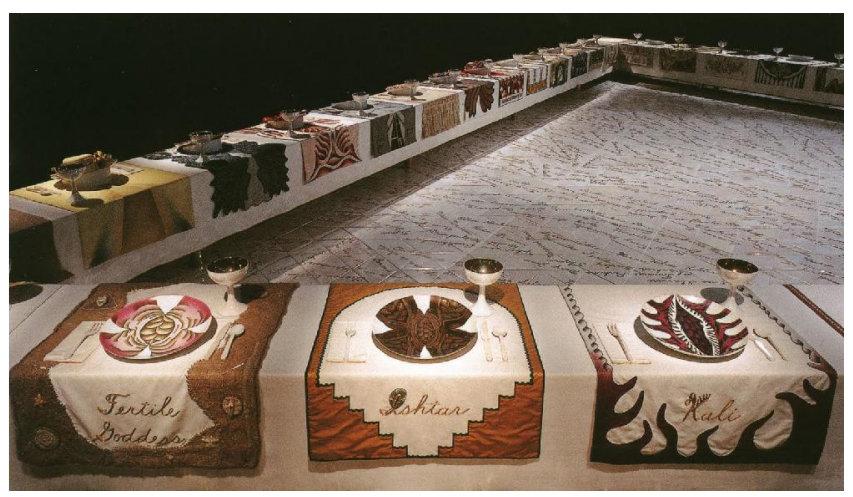

Fig. 4. The Dinner Party Judy Chicago 1979

Art works can not only show the appearance of things, but also can penetrate the nature. It will discover and show the rhythm of things, the pulse of life, and leads people to achieve the ultimate thinking about nature, society and the meaning of life.

In the development of arts, artists have used their art practice continue to enrich the attics connotation and form, changing the concept of art. The modern value of art is shown as constantly changing impression of art to people in the art field. Throughout the history of Western art, we find it is also a history of seeking real since ancient Greece. It is namely how to observe nature and objects, and using canvas or clay to correctly conduct plane or stereo reproduction.[6] However, when the camera was invented, people simply press the shutter to get pictures which are also have accurate perspective, light and shade and texture as the painting. This mercilessly replaces the realist technique that pursued and accumulated by painters during long periods of time.

Artists began to reconsider the question, what is art. And the emergence of Dada and pop art is more confusing. In 1914 the artist Marcel Duchamp invented the concept of Ready Made Art. He names the urinal as the fountain, and hoped to attend the exhibition of France salon, but was turned down. He expressed the rebellion to traditional art by painting beard on the coupled of Mona Lisa. Contemporary forms of artistic expression are stimulated the nerves of art critic and audience. But all the changes of art might be the forms. [7]The rational connotation of art does not change. It just the forms of art are more freely and directly, and these changes will require a process of judging and absorption.

\section{CONCLUSIONS}

It will be better to clarify the overall process of artistic value realization from the perspective of communication. Artists are the creators of artistic value and the prerequisite for realization; Art audience is the ultimate beneficiaries of artistic value; Artistic value can be measured through the communication effects. In addition, the discussion on artistic value is a dynamic process with the development of arts. We discuss it not only from the ontology of art, but also from a macro perspective of social and artistic fields. The modern 
value of arts is not only the value of awareness, educational and aesthetic in the traditional sense, the influence to society and the field of art itself is also one of its great value. From the artist side, art work is undoubtedly externalization and idealistic of the artist's concept. Although it gained a certain degree of substantiality from the symbols or images, on the whole it's still part of the concept of abstract things. Its reality obtained from the relationship of arts recipient. Therefore, in the relationship between works and recipient, art work undoubtedly constitutes the material undertaker of artistic value. It also became the object, and also constitutes the premise and basis of value relations to be established. The important state of art works in the value relations, on the one hand regulated the direction, scope and limits of art recipients; on other hand, art work directly determines the choice of art recipients. Arts communication is the necessary link between artistic creation and appreciation, especially in the modern media environment. The realization of artistic value relies on the effective dissemination of art information.

\section{REFERENCES}

[1] Malcolm Budd, Values of Art: Pictures, Poetry, and Music,1st ed., Penguin Books, 1997, pp.102-103.

[2] H. W Janson, History of Art, 4th ed.,Harry N. Abrams, Inc., 1991, pp.126-128.

[3] Peyton Paxson, Mass Communications and Media Studies: An Introduction, 1st ed., Bloomsbury Academic, 2010, pp.62-66.

[4] Gary Iseminger, The Aesthetic Function of Art, 1st ed., Cornell University Press,2004, pp.52-55.

[5] Sam Hunter, Modern Art: Painting, Sculpture, Architecture, 3rd ed., Prentice Hall College Div, 2000, pp.202-203

[6] George Dickie, Art and Valu, 1st ed., Wiley-Blackwell, 2001, pp.2225.

[7] Stephen Davies, The Philosophy of Art, 1st ed., Wiley-Blackwell, 2006, 232-235. 